\title{
Integrating the Thought of Mencius and Xunzi and the Problem of Modernizing Chinese Society
}

\author{
Huang Yushun 黃玉順 \\ Professor of Philosophy, Collaborative Innovation Center of Confucian \\ Civilization, Shandong University, Jinan, China \\ hyso531@163.com
}

\begin{abstract}
How should people today deal with the teachings of Mencius 孟子 and Xunzi 荷子? This is a question of utmost importance in reviving Confucianism. The thought of Mencius and Xunzi has many inherent complexities and contradictions. After all, they have been revised, reconstituted, and reused alongside shifts in lifestyles and social structures; their respective influence also waxed and waned accordingly. Xunzi's teachings flourished during China's transition from monarchical feudalism to imperial autocracy, an indication that Xunzi's thinking has Legalist elements. The rulers in the imperial period adopted "sole veneration of Confucian learning" [ du zun rushu 獨尊儒術], so the suspiciously Legalist teachings of Xunzi went into decline while the orthodox Confucian teachings of Mencius were on the rise. At the same time, Xunzi's thought continued to play an important, perhaps even fundamental, role in hidden ways. This is the political path of being “openly Confucian, covertly Legalist” [ yang ru yin fa 陽儒 陰法] practiced under autocratic authority. As Chinese society began to modernize, Xunzi's teachings enjoyed a revival, revealing that some of its strains were compatible with modern Enlightenment ideas. Further, this modern revival of Xunzi occurred on the heels of a Confucian revival. The fact that the two then more or less continued to coexist indicates the need to rethink the two schools of thought in an integrated way. To do this, I take a page from modern value systems and consider the existing distinctions between Mencius's and Xunzi's thinking via a "profit and loss analysis."
\end{abstract}

\section{Keywords}

integration - Mencius - modernizing Chinese society - Xunzi 
How should people today approach the thought of Mencius 孟子 [372-289 вCE ] and Xunzi 荀子 [313-238 BCE]? With approval or dismissal? As juxtaposed or integrated entities? Even contemporary scholars who tend to share similar values engage in endless debate over these questions because it is possible to find in the texts of Mencius and Xunzi evidence supporting both sides of their arguments. This reflects the many existing complexities and contradictions in the thought of Mencius and Xunzi; to attempt to use them to demonstrate or prove contemporary research and ways of thinking is not sound. Instead, I observe the rise and fall of each during key shifts in China's social structure to confirm the attitude that we, as contemporary people, should take with regard to the thought of Mencius and Xunzi.

In a previous essay, I argued that existing histories of Confucianism as well as Chinese thought "tend to depart from a sense of the historical periods discussed, functioning essentially as an intellectual exercise and obscuring the actual characteristics of Confucianism's historical contexts.... Narratives of Confucianism which treat it as an echo-chamber existing apart from reality and life ... obscure or bury important questions of historical change."1 In reality, any way of thinking is a product of its times; its influence both during and after its times will rise and fall in tandem with changes and shifts in society. In premodern China, a particularly intimate relationship always existed between thought and scholarship and the politics of its time, as can be seen in the fact that the Hundred Schools of Thought all "took governance as its purpose" [wu wei zhi zhe 務為治者]. ${ }^{2}$ Therefore, what is known as "the thought of Mencius and Xunzi" is, in fact, the thought of Mencius and Xunzi as interpreted and applied throughout different periods. Aspects of their thinking are bound to be emphasized, exaggerated, and altered in this continual process of reconstruction. The primary question of concern in this discussion is how the thought of Mencius and Xunzi should be reconstructed and integrated within China's current movement toward modernization?

1 Huang Yushun 黃玉順, “Lun 'chong xie ruxue shi' yu 'ruxue xiandaihua banben' wenti 論“重寫儒學史”與“儒學現代化版本”問題 [On the Problem of 'Rewriting the History of Confucianism' and 'the Modernized Version of Confucianism']," Xiandai zhexue 現代哲學, no. 3 (2015).

2 Sima Qian 司馬遷, “Taishigong zixu 太史公自序 [The Grand Historian's Personal Account]," in Shiji 史記 [Records of the Grand Historian] (Beijing: Zhonghua shuju, 1959), 3288-89. 


\section{The Shifting Influence of Mencius and Xunzi and the Emergence of China's Autocratic Empire}

Throughout the past two thousand years of Chinese intellectual history, the schools of thought of Mencius and Xunzi have gone through many ups and downs in influence. Xunzi's influence was stronger from the end of the Warring States period [475-221 BCE] to the early years of the Eastern Han dynasty $\left[25^{-220}\right.$. Starting in the latter years of the Eastern Han dynasty, Mencius's teachings steadily gained ground while Xunzi's thought officially went into decline while maintaining practical application behind the scenes. In the period from the Ming [1368-1644] to the Qing [1644-1911] dynastiesespecially during the latter-Xunzi's thought enjoyed a steady revival even as Mencius's maintained its stable position of influence. To understand these shifting trends, one must look beyond the teachings of Mencius and Xunzi to understand the development and the changing structure of Chinese society. As I have written elsewhere, the social history that best helps us understand these shifts can be delineated as follows:

1. the era of clan-based monarchical kingdoms: the Shang [16о0-1046 вСЕ] to the Zhou [1046-256 BCE] dynasties

2. the first great social upheaval: the Spring and Autumn period [770476 в С $]$ to the Warring States period

3. the era of hereditary imperial autocracy: from the Qin [221-207 BCE] to the Qing dynasties

4. the era of individual human rights: Republican period [1912-1949]

5. the second great social upheaval: the modern period to the present.

\subsection{The Heyday of Xunzi's Teachings and the First Great Social Upheaval}

The practice of referring to Confucianism as "the Way of Confucius and Mencius" [Kong Meng zhi dao 孔孟之道] is a relatively recent practice. ${ }^{3}$ Liang Yusheng's 梁玉繩 [1745-1819] claim that "the practice of placing the names of Mencius and Xunzi side-by-side began with Confucian scholars of the Han" is an overstatement. ${ }^{4}$ Xu Fuguan's 徐復觀 $[1903-1982]$ observation that "based on the general intellectual trends of the early Eastern Han, the influence of

3 The phrase “Kong Meng zhi dao 孔孟之道 [the Way of Confucius and Mencius]” first appears in chapter 6o of Romance of the Three Kingdoms in the late Yuan to early Ming dynasty. See Luo Guanzhong 羅貫中, Sanguo yanyi 三國演義 [Romance of the Three Kingdoms] (Beijing: Renmin wenxue chubanshe, 1973), 514.

4 Liang Yusheng 梁玉繩, Shiji zhiyi 史記志疑 [Inconsistencies in the Records of the Grand Historian] (Beijing: Zhonghua shuju, 1981), 36.1481. 
Xunzi far overshadowed that of Mencius" is more historically accurate. ${ }^{5}$ In fact, it is not just during the early Han but throughout the entire Han period [202 BCE-220], perhaps even beyond, that Xunzi's influence was greater.

As to how this came to be, many scholars attribute it to issues of textual transmission following the Qin dynasty's burning of books. As Wang Zhong 汪中 [1744-1794] writes, "Most schools of Confucian thought were unable to establish a foothold during the Han. After weathering the violent upheavals of the Warring States period and Qin dynasty, it was mostly due to Xunzi's thought that the Six Arts of Confucianism could be transmitted." ${ }^{\prime 6}$ Liang Qichao 梁啟超 [1873-1929] writes, "though, after the fall of the Han dynasty, the official position was to develop and venerate the teachings of Confucius, the sect of Confucianism that was actually passed down was Xunzi's." ${ }^{7}$ In addition, some scholars believe that:

Among the Han period Confucian scholars, it was not just those classically trained, such as Fu Qiubo 浮丘伯, Fu Sheng 伏生, and Master Shen 申公, who began studying Xunzi; even the Confucians whom they acknowledged-such as Lu Jia 陸賈, followed by Yang Xiong 揚雄, Wang $\mathrm{Fu}$ 王符, Zhong Changtong 仲長統, and Xun Yue 荀悅一were without exception inheritors of Xunzi's thought. It seems that in the academic realm of the two Han dynasties ... nearly all Confucian scholars of note were followers of Xunzi's philosophy. ${ }^{8}$

Although none of these statements are false, they are but superficial observations.

It is not incidental that the rise of Xunzi's thought should occur during the "first great social upheaval," the period of China's transition from monarchical feudalism to imperial autocracy. Xunzi conformed to the direction of social change in his time, one that ideologically embodied Legalist thought. Xunzi's thought is essentially the melding of Confucianism and Legalism. As

5 Xu Fuguan 徐複觀, Liang Han sixiang shi 兩漢思想史 [Intellectual History of the Two Han Dynasties] (Shanghai: Huadong shifan daxue chubanshe, 2001), 2.310.

6 Wang Zhong 汪中, Shuxue jiaojian 述學校箋 [A Collation and Commentary on the Shuxue] (Beijing: Zhonghua shuju, 2014), 453.

7 Liang Qichao 梁啟超, “Zhongguo xueshu sixiang bianqian zhi dashi 中國學術思想變遷之 大勢 [General Trends in Intellectual Shifts in Chinese Scholarship]," in Yin bing shi he ji 飲冰 室合集 [Collected Works from the Ice-Drinking Room], ed. Liang Qichao (Beijing: Zhonghua shuju, 1989), 7.49.

8 Xu Pingzhang 徐平章, Xunziyu liang Han Ruxue 荀子與兩漢儒學 [Xunzi and Confucianism of the Two Han Dynasties] (Taibei: Wenjin chubanshe, 1988), 179. 
Liang Qichao has written, "Xunzi was born during the Warring States period, a time when Legalists were already established. The two schools drew on and influenced each other. Thus, the rites [ $l i$ 禮] of which Xunzi speaks are very close to the laws [ $f a$ 法] put forth by Legalists. The nature of the two is actually quite similar."

Indeed, not only did Xunzi cultivate two exceptional Legalist disciples-Han Fei 韓非 [280-233 в B E ] and Li Si 李斯 [284-208 BCE], who would respectively serve as the great theorist and great politician of the tyrannical Qin dynastybut his own teachings also include elements of despotism. Tan Sitong 譚嗣同 [1865-1898] has a famous saying: "Two thousand years of governance all mirror the politics of the Qin dynasty; it is a politics based on usurpation. Two thousand years of thought all boil down to Xunzi's teachings; they merely reflect the desires of country folk."10 Despite the extreme wording, the meaning is not hard to grasp. Tan's invective is directed at the "overtly Confucian, covertly Legalist” [yang ru yin fa 陽儒陰法] form of state-sanctioned Confucianism ushered in with imperial autocracy. Liang Qichao has also remarked: "What has been in practice for two thousand years is in reality the political system of the Qin dynasty, and its true nature can be found in Xunzi's political ideology."11 Other scholars claim that "Xunzi is the true 'godfather' who has overseen the more than two-thousand-year-old political system of single-ruler autocracy in place since the Qin."12 Some even believe that Xunzi advocated serving tyrannical rulers. ${ }^{13}$ It is apparent that the flourishing of Xunzi's thought was due to

9 Liang Qichao, Xian Qin zhengzhi sixiang shi 先秦政治思想史 [An Intellectual History of the Early Qin] (Tianjin: Tianjin guji chubanshe, 2003), 117-18.

10 Tan Sitong 譚嗣同, Tan Sitong quanji 譚嗣同全集 [The Complete Works of Tan Sitong], ed. Cai Shangsi 蔡尚思and Fang Xing 方行 (Beijing: Zhonghua shuju, 1981), 2.337.

11 Liang Qichao, "Lun zhina zongjiao gaige 論支那宗教改革 [On Chinese Religious Reform]," in Yin bing shi heji, 3.57.

12 Zhao Fasheng 趙法生, “Xunzi de zhengzhi sheji yu xuepai guishu 軥子的政治設計與學 派歸屬 [Xunzi's Political Designation and the School of Thought to Which He Belongs]," Zhexue yanjiu 哲學研究, no. 5 (2016).

13 See Chang Daqun 常大群, “Xunzi yu Zhongguo junzhu zhuanzhi zhengti 荷子與中國君 主專制政體 [Xunzi and Chinese Autocratic Governance]," Zaozhuang shizhuan xuebao 東莊師專學報, no.1 (1992); Fang Erjia 方爾加, Xunzixin lun 荀子新論 [New Discussions on Xunzi] (Beijing: Zhongguo heping chubanshe, 1993), 46-5o; Fang Erjia, "Xunzi: Kong Meng Rujia de qiangu zuiren 荀子: 孔孟儒家的千古罪人 [Xunzi: Eternal Sinner of Orthodox Confucianism]," Guan zi xuekan 管子學刊, no. 4 (1994); Sa Mengwu 薩孟武, Zhongguo zhengzhi sixiang shi 中國政治思想史 [History of Chinese Political Thought] (Beijing: Dongfang chubanshe, 2008), 29-30; Wang Ling 王玲, "Xian Qin Rujia de 'jun chen zhi fen' tan ze 先秦儒家的“君臣之分’探賾 [Investigation into the Pre-Qin Confucian Idea of 'Division between Lord and Servant']," Hebei shifan daxue xuebao 河北 師範大學學報, no. 2 (2012). 
its elements that are ideologically compatible with imperial autocracy. This is something that we must be particularly wary of when it comes to the today's revival of Xunzi's doctrine.

\subsection{The Heyday of Mencius's Teachings and the Era of Imperial Autocracy}

Curiously, although Xunzi's thought seems well suited to a system of imperial autocracy, it went into decline at the start of the imperial era. Of course, this decline did not signal that imperial rulers had abandoned Xunzi's doctrine or even Legalism, for that matter. Scholars generally agree that nearly all the ruling houses in imperial China took the path of being "openly Confucian and covertly Legalist.” As the Han emperor Xuan 漢宣帝 [r. 74-49 BCE] famously said, "the Han ruling house has our unique system of governance based on simultaneously following the Way of the tyrant and the Way of the king."14 "The Way of the king" points to Confucian ideas whereas "the Way of the tyrant" references Legalist thought. One might even say that this idea beats within the hearts of all dynastic emperors. Another classic example of this is the fact that both Mou Zongsan 牟宗三 [1909-1995] and Li Zehou 李澤厚 consider Zhu $\mathrm{Xi}$ 朱喜 [1130-1200] and Xunzi to be of the same ilk. In his assessment, Mou goes so far as to say Zhu Xi was "speaking of Confucius's humanity [ren 仁] with Xunzi's disposition." ${ }^{15} \mathrm{Li}$, however, admires Zhu Xi for "raising Mencius's banner while practicing Xunzi's doctrine."16 It would seem that, in the history of imperial China, state-sanctioned Confucianism almost always included elements of Xunzi's doctrine, with varying degrees of integration between Confucianism and Legalism, depending on how each ruling house negotiated being "openly Confucian and covertly Legalist."

All the same, even if only in name, Xunzi's teachings, indeed, went into decline. There was a time in imperial China when the Tang dynasty [618907] figure Yang Liang's 楊倞 [fl. 823] annotated edition of the Xunzi enjoyed widespread influence, but even this could not change the course of history. Yang was a subordinate of Han Yu 韓愈 [768-824] (in his preface, he refers to Han as "Deputy Minister Han"). ${ }^{17}$ It has also been established that, "in the

\footnotetext{
14 Ban Gu 班固, “Yuandi ji 元帝記 [Annal of Emperor Yuan]," in Han shu 漢書 [History of the Former Han Dynasty] (Beijing: Zhonghua shuju, 1962), 277.

15 Mou Zongsan 牟宗三, Xinti yu xingti 心體與性體 [Substance of the Mind and of Nature] (Changchun: Jilin chuban jituan youxian gongsi, 2013), 41.

16 Li Zehou 李澤厚, “Lun lixue buzhu 倫理學補注 [Additional Annotations to Discussions of Neo-Confucianism]," Tansuo yu zhengming 探索與爭鳴, no. 9 (2016).

17 Huo Shengyu 霍生玉, "Han Yu zhushi guo Xunzi ma? Tangdai Yang Liang Xunzi zhu zhong 'Han shilang' kao 韓愈注釋過《荀子》嗎一唐代揚倞《荀子注》中 ‘韓侍
} 
past, the writings of both Xunzi and Yang Xiong 揚雄 [53 BCE-18] were revised and edited by Han Yu and Liu Zongyuan 柳宗元 [773-819]."18 Nevertheless, Han $\mathrm{Yu}$, who founded the pro-Mencius anti-Xunzi neo-Confucianism in the Song [960-1279] to Ming dynasties, believed that, when it came to Confucian orthodoxy, "the works of Xunzi and Yang Xiong, while possessing their worthwhile aspects, are unrefined; while excelling in rhetoric, they lack thoroughness."19 Thus, he disparaged them.

For what reasons, then, did Xunzi's teachings go into decline, and why did imperial rulers, having chosen to adhere to Confucianism, nevertheless distance themselves from Xunzi's strain of Confucianism? To understand this, one must look more closely at the idea of being "openly Confucian, covertly Legalist." On the one hand, openly applying Confucianism meant raising the banner of Confucianism when it came to extolling ideas of "the kingly Way" and "benevolent rule." The imperial system achieved stability during the period when the Han dynasty inherited its political system from the Qin dynasty. This political "grand unification" required an accompanying ideological "grand unification"; this resulted in "discarding all other ways of thinking, venerating solely Confucian teachings." ${ }^{20}$ Dong Zhongshu 董仲舒 [179-104 BCE] writes: "As for the schools of thought that do not espouse the Six Classics and the sects that diverge from Confucian teachings, we must cut off all avenues of dissemination so that they cannot develop in tandem with Confucianism." ${ }^{21}$ In reality, the Han imperial decision to venerate Confucianism exclusively did not originate with Dong; rather, it was a process involving a collective shift in ideology. It is recorded in the "Biographies of Confucian Scholars" [Rulin liezhuan 儒林列傳] section of the Records of the Grand Historian [Shiji 史記] [by Sima Qian] that "the veneration of Confucianism goes back to the time of the Han emperor Wu's 漢武帝 [r. 141-87 BCE] instatement as well as the appointments of Lord Weiqi 魏其侯 and Lord Wu'an 武安侯 as chancellors." Furthermore:

After the Dowager Empress Dou's 䆩太后 passing, Tian Fen 田蚡, the lord of Wu'an, became a chief minister. He banished the teachings of the

郎' 考 [Did Han Yu Ever Annotate the Xunzi? A Study of 'Deputy Minister Han' in the Annotated Xunzi of Tang Dynasty Figure Yang Liang]," Guji yanjiu 古籍研究, no. 2 (2013).

18 Ruan Yi 阮逸, annot., "Zhongshuo 中說 [Discourses on the Mean]," in Sibu congkan chubian 四部叢刊初編 [First Series of the Four Branches of Literature Collection], 338.3.

$19 \mathrm{Han} \mathrm{Yu}$ 韓愈, Han Changli wenji jiaozhu 韓昌黎文集校注 [Annotated Collected Works for Han Changli], annot. Ma Qichang 馬其昶 (Shanghai: Shanghai guji chubanshe, 1987), 18.

20 Ban Gu 班固, "Dong Zhongshu zhuan 董仲舒傳 [Biography of Dong Zhongshu]," in Han shu, 2523.

21 Ban Gu 班固, “Dong Zhongshu zhuan," 2525. 
Huang-Lao, the Legalists, and the school of "performance and title" [xingming 刑名] as well as the discourses of the Hundred Schools of Thought. He also invited hundreds of Confucian scholars.... Since then, it has become the norm for all scholars under Heaven to dedicate themselves to the study of Confucianism. ${ }^{22}$

These accounts reveal that it is not just Xunzi's teachings but also aspects of traditional Confucianism that serve the needs of imperial autocracy. This is another point that people today must understand.

On the other hand, covertly applying Legalism is necessary, as one cannot openly support the despotism of the Legalist school without risking being known for tyranny. Although Xunzi's teachings fall under the umbrella of Confucianism, they had Legalist leanings. An imperial government that claimed to model itself on the principles of "kindness and virtue" as well as "filial governance of all under Heaven" could not very well draw on a school such as Legalism, which tended to be associated with the Qin. Therefore, Xunzi's teachings could only "work behind the scenes."

Thus, in accordance with the "sole veneration of Confucian learning" [ du zun rushu 獨尊儒術], the teachings of Mencius, who was the only major Confucian figure who had standing equal to that of Xunzi, flourished. In the late Eastern Han dynasty, Zhao Qi 趙岐 [d. 201] put forth the earliest annotated version of the Mencius, titled Chapters and Sentences in the Mencius [Mengzi zhangju 孟子章句]. In Han Yu's discussion of Confucian orthodoxy in the "Original Way" [Yuan dao 原道], we find the first official endorsement of Mencius and criticism of Xunzi. Thereafter, the emergence of neo-Confucianism in the Song dynasty represents the zenith of Mencius's influence.

At the same time, it is important to keep in mind that the doctrines of Mencius that flourished from the Tang to the Song dynasties are not Mencius's original teachings but, rather, his teachings as explicated and revised by the Song dynasty neo-Confucians Cheng Hao 程影 [1032-1085], Cheng Yi 程頣 [1033-1107], and Zhu Xi. Further, this transmission of Mencius's teachings was not always endorsed by the dynastic ruling house. For instance, the Ming dynasty emperor Zhu Yuanzhang 朱元璋 [r. 1368-1398] did not care for them; they did, however, find great favor with the Qing imperial rulers. As Mencius had very little to do with autocratic thinking and was, in fact, harshly critical of

22 Sima Qian, “Ru lin lie zhuan 儒林列傳 [Biographies of Confucian Scholars]," in Shiji, 3118. The English rendering of xingming 刑名 comes from Paul Goldin. See "Han Fei and the Han Feizi," in Dao Companion to the Philosophy of Han Fei, ed. Goldin (Dordrecht: Springer, 2013), 1-21. 
such tendencies, it is not surprising that the Qing rulers would find the revised and explicated version of his teachings better suited for their use.

\section{The Revival of Mencius's Teachings and the Modern Transformation of Chinese Society}

The modern revival of Xunzi's teachings can be traced to the period from the Ming to the Qing dynasties and to figures such as Fu Shan 傳山 [1607-1684] and Fei Mi 費密 [1623-1699]. The use of "modern" here refers to the emergence of an "endogenous modernity" that can be traced to the "Tang-Song transformation” [Tang Song bian'ge 唐宋變革 ${ }^{23}$ and was especially evident during the Ming and Qing dynasties. ${ }^{24}$ It was the Qing Confucian scholars active during the reign of Qianlong 乾隆 [r. 1735-1796] and Jiaqing 嘉慶 [r. 1796-1820]—the socalled Qianjia school [Qianjia xuepai 乾嘉學派] 一who openly sought to revive Xunzi's thought. This included famous scholars such as Lu Wenchao 盧文弨 [1717-1795], Xie Yong 謝墉 [1719-1795], Qian Daxin 錢大听 [1728-1804], Wang Zhong, Ling Tingkan 淩廷堪 [1757-1809], and Hao Yixing 郝懿行 [1757-1825].

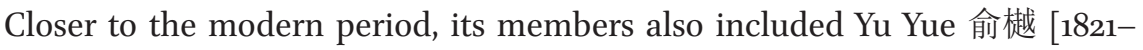
1907], Wang Xianqian 王先謙 [1842-1917], and Sun Yirang 孫詒讓 [1848-1908].

Many have connected this period's revival of Xunzi's philosophy to the rediscovery of pre-Qin philosophy via Qianjia school scholars rummaging through ancient texts. However, this is but a superficial account of what was happening. Han Learning [Han xue 漢學], which was popular among Qing dynasty Confucians (e.g., the Qianjia school), "came to be through opposition to Song Learning [Song xue 宋學]."25 "Song Learning” refers here to the neo-Confucian school led by the two Chengs and Zhu Xi, which formed the ideological backbone of Qing imperial autocracy. Thus, for Qianjia scholars to revive Xunzi's thought was a subtle challenge to the political ideology of the empire.

23 Naitō Torajirō 内藤湖南, “Gaikatsu teki Tōsō jidai kan 概括的唐宋時代観 [A General Perspective on the Period from the Tang to Song Dynasties]," Rekishi to chiri 歴史と 地理 [History and Geography] 9, no. 5 (1910). For a Chinese translation, see Liu Junwen 劉俊文, ed., Riben xuezhe yanjiu Zhongguo shi lunzhu xuanyi 日本學者研究中國史論 著選譯 [Select Translations of Chinese Historical Research by Japanese Scholars] (Beijing: Zhonghua shuju, 1992), 1.10-18.

24 See Huang Yushun, “Lun 'chong xie Ruxue shi”; idem, “Lun ruxue de xiandai xing 論儒 學的現代性 [On the Modernity of Confucianism],” Shehui kexue yanjiu 社會科學研究, no. 6 (2016).

25 Zhou Yutong 周予同, Zhou Yutong jingxue shi lunzhu xuanji 周予同經學史論著選集 [Collection of Select Works by Zhou Yutong on the History of Classical Studies] (Shanghai: Shanghai renmin chubanshe, 1996), 323. 
Qianjia Confucians have two qualities that can be considered "modern". The first is their method, which was based on seeking truth from facts. As Liang Qichao said, "The research style of the Qianjia scholars was based on reality as it is. It is similar to today's scientific method. We can thus call them the scientific classical school." ${ }^{26} \mathrm{Hu}$ Shi 胡適 [1891-1962] also remarked that "their method and spirit reflect positivism, whose hallmark is the presentation of evidence."27 The second way in which they are modern is their way of thinking, which recalls Enlightenment thinking. Dai Zhen's 戴震 [1724-1777] work Evidential Analysis of the Terms in the Mencius [Mengzi ziyi shuzheng 孟子字 義疏証] is a classic example of this. While venerating Mencius, this work also acknowledges aspects of Xunzi's ideas. In the words of Zhang Taiyan 章太炎 [1869-1936], "Dai Zhen's beliefs are largely in agreement with those of Xunzi."28 Qian Mu 錢穆 [1895-199o] wrote, "Although [Dai Zhen] shares Mencius's belief in the basic goodness of human nature, his rhetoric is often closer to Xunzi's."29 Put another way, one could say that the teachings of both Mencius and Xunzi have elements that work together to resist the ideological premise of imperial autocracy and despotism.

A more recent sign of Xunzi's revival is in the debate that emerged in the academic context of the late Qing between New Text Confucians (i.e., Xia Zengyou 夏曾佑, Tan Sitong, Liang Qichao) who wished to suppress Xunzi's thought and the Old Text School of Confucians (i.e., Yu Yue, Zhang Taiyan), who advocated for Xunzi's thought. The movement to suppress Xunzi took place largely during the period from 1895, the year of China's defeat in the first Sino-Japanese War, to 1898 , the failure of the Hundred Days' reform movement. Both events are consequences of the autocratic system in place since the Qin dynasty. Xia Zengyou believed that "autocracy as law" was established because Xunzi "served the [wise] ruler of his time." ${ }^{30}$ Tan Sitong believed that Xunzi "acted in

26 Liang Qichao, “Zhongguo jin sanbainian xueshushi 中國近三百年學術史 [A History of Chinese Scholarship in the Past Three Hundred Years]," in Yin bing shi heji, 10.22.

$27 \mathrm{Hu}$ Shi 胡適, Hu Shi yigao ji micang shuxin 胡適遺稿及秘藏書信 [Unpublished Manuscripts and Private Letters of Hu Shi] (Hefei: Huangshan shushe, 1994), 7.49.

28 Zhang Taiyan 章太炎, Zhang Taiyan quanji 章太炎全集 [The Complete Works of Zhang Taiyan] (Shanghai: Shanghai renmin chubanshe, 1985), 4.24.

29 Qian $\mathrm{Mu}$ 錢穆, Zhongguo jin sanbainian xueshushi 中國近三百年學術史 [A History of Chinese Scholarship in the Past Three Hundred Years] (Shijiazhuang: Hebei jiaoyu chubanshe, 1999), 311.

30 Zhu Weizheng 朱維錚, "Shenzhou changye shui zhi jiu: xi Xia Zengyou yu Song Shu de tongxin 神州長夜誰之处一析夏曾佑與宋恕的通信 [Whose Error During a Long Night in Shenzhou: Analyzing the Correspondence between Xia Zengyou and Song Shu]," in Yindiao weiding de chuantong 音調未定的傳統 [Collected Works of Zhu Weizheng], ed. Zhu Weizheng (Hangzhou: Zhejiang daxue chubanshe, 2011), 146-48. 
Confucius's name, but betrayed Confucius's way by claiming one should 'serve the wise ruler of one's time and follow the great unifying vision of that ruler."31 It has been remarked that "by taking a position to get rid of Xunzi's thought," Liang Qichao "wished to express his opposition to both political and academic despotism."32 On the other side of this debate were those who advocated following Xunzi's teachings. In the opening passage of Writings to Incite Action [Qiu shu 訄書], Zhang Taiyan writes that "following Xunzi is the first step." 33 Certainly, Zhang is known to have had Legalist leanings, as can be seen in this apologist passage: "applying the strictness of Legalism is what ultimately allows the people to work and live in peace; applying Legalist systems and regulations ultimately allows the people to profit and prosper." ${ }^{34}$ At the time this passage was written, there was a real need for revolution in China; however, the tendency for revolution to lead to authoritarian autocracy is also a modern political phenomenon. This aspect of Xunzi somewhat recalls Machiavelli. ${ }^{35}$

The point focuses attention on a contradiction: how does Xunzi's thought, which helped establish imperial authority in the early Han dynasty, come to enjoy a revival when the historical tides in China were shifting toward antiimperialism? The only explanation is that some elements of Xunzi's teachings can deconstruct imperial rule. The most conspicuous example of this is Xunzi's belief that "human nature is evil" but that "if one works to change one's nature, one can give rise to different behavior in the future." The resonance between

31 Tan Sitong 譚嗣同, Ren xue 仁學 [Study on Benevolence] (Beijing: Huaxia chubanshe, 2002), 95 .

Sun Dakun 孫大坤, “Wan Qing yujing zhong de Xunxue jieshi 晚清語境中的荷學解釋 [Explaining Xunzi in the Context of the Late Qing],” in Jingdian yu Jieshi 經典與解釋 [Classics and Explications], ed. Lou Lin 娄林 (Beijing: Huaxia chubanshe, 2018), 49.211-31. Zhang Taiyan, Zhang Taiyan quanji, 3.7.

34 Zhang Taiyan, Zhang Taiyan quanji, 79-82.

35 Huang Yushun, “Rujia ziyou zhuyi dui 'xin ru jiao' de piping 儒家自由主義對 ‘新儒教’ 的批評 [Confucian Liberalist Critique of 'New Confucian Teachings'], Dongyue lun cong 東获論叢, no. 6 (2017); idem, "Dalu xin Rujia zhengzhi zhexue de xianzhuang yu qianjing 大陸新儒家政治哲學的現狀與前景 [The Current State and Future Prospects of New Confucian Politics on the Mainland]," Hengshui xueyuan xuebao 衡水學院學報, no. 2 (2017); idem, "Ruxue zhi dangqian taishi yu weilai zhuwang 儒學之當前態勢與未來 矚望 [The Current State and Future Hopes of Confucian Studies]," Kongzi yanjiu 孔子 研究, no. 4 (2018); idem, "Ruxue de xianzhuang, jiaoxun yu jingyan: zhengzhi zhexue cengmian de guancha yu sikao 儒學的現狀, 教訓與經驗: 政治哲學層面的觀察與思 考 [The Current Situation, Lessons, and Experiences of Confucian Studies: Observations and Considerations of Political and Philosophical Aspects]," in Shenghuo ruxue yu xiandaixing wenti 生活儒學與現代性問題 [Living Confucianism and the Problem of Modernity], ed. Huang Yushun (Chengdu: Sichuan renmin chubanshe, 2019). 
this idea and discussions of "natural state" in the Enlightenment movement has been discussed at length by many scholars.

\section{$3 \quad$ Integrating the Thought of Mencius and Xunzi and the Modern Turn of Confucian Philosophy}

That the modern revival of Xunzi's thought did not result in the decline of Mencius's influence breaks the long historical pattern of their mutual incompatibility. Their new relationship, instead, resembles Hegelian incorporation. It is no wonder that arguments for integrating the thought of Mencius and Xunzi have become a recent trend in academia.

\subsection{The Scholarly Trend of Integrating Mencius and Xunzi}

As part of this recent trend, Li Zehou's 2017 suggestion that we inherit both schools of thought played an influential role. The call to "raise Mencius's banner while practicing Xunzi's doctrine" that he advocates is "a way of using an ontologically emotional worldview together with a religious morality to model and build a fitting public, rational, and modern social ethics." ${ }^{36}$ He goes on the label the latter ("religious morality") a "modern form of Xunzi's doctrine" and the former ("ontologically emotional worldview") a "modern form of Mencius's banner." Further, "such 'mutual exploitation between Confucianism and Legalism' has always been an intrinsic part of Confucianism." ${ }^{37}$ Here, "Mencius's banner" refers to the emotional dimension of ethics while "Xunzi's doctrine" points to the dimension of ethics that deals with agency. In any case, it makes Xunzi's Legalist tendencies quite clear and, from my perspective, dangerous. Regarding this, Li writes:

It defines ethical action by allowing an external, a priori rationale to dictate and meld with an internal ethical disposition.... By defining a system of standards based on a predetermined set of hierarchical relations, it reduces "all manner of things" - which are in fact the diverse actions taken by humans - to a set of moral concepts and ethical hypotheses that are actionable and applicable, rather than capacious and thorough. This makes for effective regulation of human conscience.... [The result

36 Li Zehou, “Ju Meng qi, xing Xun xue: wei 'lun lixue gang yao' yibian 舉孟旗, 行荀學: 為《倫理學綱要》一讋 [Raising Mencius's Banner, Practicing Xunzi's Teachings: An Argument for Lun Lixue Gangyao ]," Tansuo yu zhengming, no. 4 (2017): 60.

Li Zehou, "Ju Meng qi, xing Xun xue," 6o. 
of this] is what Tan Sitong means when he says, "Two thousand years of thought all boil down to Xunzi's teachings." Thus, Xunzi, Dong Zhongshu, and Zhu Xi comprise the ethical philosophy that has dominated China for 2,000 years. ${ }^{38}$

From this, it is clear that Li Zehou's adage may be applicable in the era that followed the path of being "overtly Confucian and covertly Legalist"; however, it is not a path that we should try to follow today as it suggests authoritarian proclivities.

As early as 2007, I brought up the question of "integrating Mencius and Xunzi." ${ }^{39}$ I once summarized my view of what Confucian thinking affords us as follows: "Whether you engage with Mencius or Xunzi, all roads go through Confucius." ${ }^{40}$ For example:

The principles of "profit" were made widely known by Western Enlightenment thinking, but one can find it in Xunzi as well. Similarly, benevolent love, a concept appropriate to the present, can also be found in Mencius.... The work we need to do is twofold: first, to find the connection between readings of Xunzi and various spiritual dimensions of Western Enlightenment thinking; and, second, to find the connection between readings of Mencius and the spiritual dimension of Western Protestantism. By doing so, we can integrate Mencius and Xunzi via Confucius. This is the way to reconstruct a "Chinese theory of justice."41

I have spent the years since bringing up the integration of Mencius and Xunzi's thought building just such a Chinese theory of justice. ${ }^{42}$ Since 2008 , I have

38 Li Zehou, "Ju Meng qi, xing Xun xue," 59.

39 Huang Yushun, Zhexue duanxiang: “Shenghuo ruxue” xinzha 哲學斷想: “生活儒學” 信答 [Fragmented Thoughts on Philosophy: Letters on Living Confucianism] (Chengdu: Sichuan renmin chubanshe, 2019), 257-63 and 293-96.

$40 \quad$ Huang Yushun, Zhexue duanxiang, 296.

41 Huang Yushun, Zhexue duanxiang, 263.

42 For more on "Chinese theory of justice," see Huang Yushun, Zhongguo zhengyi lun de chongjian: Rujia zhidu lunlixue de dangdai chanshi 中國正義論的重建: 儒家制度倫 理學的當代闡釋 [Rebuilding a Chinese Theory of Justice: Contemporary Interpretations of Confucian Systems of Human Ethics] (Hefei: Anhui renmin chubanshe, 2013); Huang Yushun, Zhongguo zhengyi lun de xingcheng: Zhou Kong Meng Xun de zhidu lunli xue chuantong 中國正義論的形成: 周孔孟荀的制度倫理學傳統 [The Making of China's Theory of Justice: The Tradition of Confucian Ethics in Zhou, Confucius, Mencius, and Xunzi] (Shanghai: Dongfang chubanshe, 2015). 
spoken regularly on the topic at a number of public presentations. ${ }^{43}$ One can say that the Chinese theory of justice is essentially the result of integrating Mencius and Xunzi into a theoretical system of Confucian justice. The method I use is similar to Feng Youlan's 馮友蘭 [1895-1990] "method of abstract inheritance." 44 That is, I rigorously teased out both the aspects of Mencius and Xunzi that deal with everyday social problems in history and the aspects of the two thinkers that transcend history. The latter tends to be a set of fundamental Confucian principles — such as "Chinese theory of justice" - and it is possible to deduce from it not only the structure of early modern systems but also the construction of modern systems. This brings up two principles that inform the Chinese theory of justice: legitimacy and suitability.

Liang Tao 梁濤 was one of the first scholars to bring up integrating the thought of Mencius and Xunzi in the conclusion of his 2008 book, The Guodian Bamboo Strips and the Si-Meng School [Guodian zhujianyu Si-Meng xuepai 郭店 竹簡與思孟學派], which he later reflects was a move that "remade Confucian orthodoxy."45 Thereafter, especially in recent years, intermittent publications have appeared on the topic, gradually developing it into a scholarly trend. Most recently, three articles published in the second issue of Literature, History, and Philosophy [Wen shi zhe 文史哲] in 2020 are representative of the state of the discussion. The first article is Liang Tao's "Transcending 'Venerate Mencius, Suppress Xunzi': Returning to Venerating Both Masters," which argues for incorporating Mencius's idea of "governing through virtue" and Xunzi's idea of "establishing a state through ritual" into one theory of political ethics. ${ }^{46}$ Whether Liang Tao succeeds in incorporating these two, however, is still up for debate. ${ }^{47}$ The second article is Liu Yuedi's 劉悅笛 “A Theory of Incorporating

43 Huang Yushun, “Ruxue dangdai fuxing de sixiang shiyu wenti 儒學當代復興的思想視 域問題 [On the Problem of Ideological Scope and Perspective Regarding the Revival of Confucianism Today]," Zhouyi yanjiu 周易研究, no. 1 (2008).

44 Feng Youlan 馮友蘭, “Zhongguo zhexue yichan di jicheng wenti 中國哲學遺產底繼承 問題 [The Problem of Inheriting of China's Philosophical Heritage]," Guangming ribao 光明日報, January 8, 1957; idem, "Zai lun Zhongguo zhexue yichan di jicheng wenti 再論 中國哲學遺產底繼承問題 [Revisiting the Problem of Inheriting China's Philosophical Heritage]," Zhexue yanjiu, no. 5 (1957).

45 Liang Tao 梁濤, “Kong Meng zhijian 孔孟之間 [Between Confucius and Mencius]," Zhonghua dushubao 中華讀書報, October 25, 2017.

46 Liang Tao, “Chaoyue zun Meng yi Xun, huigui tongzun Meng-Xun 超越尊孟抑荷, 回歸 同尊孟 [Transcending 'Venerate Mencius, Suppress Xunzi': Returning to Venerating Both Masters]," Wen shi zhe 文史哲, no. 2 (2020).

47 See Huang Yushun, “Kongzi zenyang jiegou daode: Rujia daode zhexue gangyao 孔子怎 樣解構道德: 儒家道德哲學綱要 [How Confucius Structures Ethics: An Outline of the Confucian Philosophy of Ethics]," Xue shu jie 學術界, no. 11 (2015). 
Mencius's and Xunzi's 'Heaven, Nature, Emotions, Mind': Inheriting Both Mencius and Xunzi from the New Perspective of 'Unifying Nature and Emotions via the Mind," which expands on Li Zehou's ideas of "inheriting both masters" and "Mencius and Xunzi's mutually complimentary aspects." 48 The third article is Guo Yi's 郭沂 "Received According to Xunzi, Rectified According to Mencius: Rebuilding Confucianism in the Context of Modernization," which I have found notable for "taking on the challenge of addressing Western culture."49 The reference in Guo's title to reception acknowledges that "the root of [modern] Confucian democratic thinking and intellectual discourse is the tradition of Xunzi's thought." Further, the phrase "rectified according to Mencius" reflects how "the tradition of Mencius's thought prepared the best ingredients" for us to engage in the postmodern work of "rectifying in order to repair the damage left by modernity."50 Guo's work is commendable as a contribution to conversations regarding Confucianism's modernization; however, the relationships between pre-Qin Confucianism and modernity and between modernity and postmodernity warrant further discussion..$^{51}$

\subsection{The Intellectual Path of Integrating Mencius and Xunzi}

To this day, scholars who advocate for the integration of Mencius and Xunzi still have not reached any conclusions about how exactly one should go about doing so. From my perspective, so long as the thought of Mencius and Xunzi has inherit contradictions, reductively expressed prescriptions such as "raising Mencius's banner while practicing Xunzi's doctrine" have little meaning. Is the banner for Mencius being raised in the name of his ethics of lord-servant relations or his critique of autocracy? Is the Xunzi doctrine that we should put in practice the aspects that fuel autocratic thinking or Enlightenment thinking? It should be clear by now that integrating the philosophies of these two thinkers requires us to exercise a profit and loss analysis. (Profit and loss can also

48 Liu Yuedi 劉悅笛, “Meng Xun 'tian, xing, qing, xin' tonghe lun: cong 'xintong qingxing' xinshijiao jiantiao Xun Meng 孟荀‘天, 性, 情, 心’ 統合論: 從“心統情性’新視角兼 祧荀孟 [A Theory of Incorporating Mencius's and Xunzi's 'Heaven, Nature, Emotions, Mind': Inheriting Both Mencius and Xunzi from the New Perspective of 'Unifying Nature and Emotions via the Mind']," Wen shi zhe, no. 2 (2020).

49 Guo Yi 郭沂, "Shou zhi yi Xun, jiu zhi yi Meng: xiandaihua beijing xia de Rujia chongjian 受之以荀, 糾之以孟: 現代化背景下的儒家重建 [Received According to Xunzi, Rectified According to Mencius: Rebuilding Confucianism in the Context of Modernization]," Wen shi zhe, no. 2 (2020).

$50 \quad$ Guo Yi, "Shou zhi yi Xun, jiu zhi yi Meng," 104.

$5^{1} \quad$ See Huang Yushun, "Lun ruxue de xiandaixing." 
be found in Confucianism, in which "loss" means to divest oneself of some old things, and "profit" means acquiring some new things. $)^{52}$

3.2 .1

Profit-Loss Analysis of the Thought of Mencius and Xunzi Based on Their Mutual Compatibility

As Mencius and Xunzi both represent Confucian schools of thought, they are compatible in some areas. For instance, where Mencius says, "all persons have the capacity to become Yao or Shun,"53 Xunzi says, "any ordinary person walking on the street can become Yu. ${ }^{54}$ Both believe in the fundamental equality of humans, a precious resource Confucianism provides in modern times. Another example can be found in the fact that Mencius, while not in favor of autocracy, does support monarchism. He and Xunzi share the belief from Confucian ethics regarding lord-servant relationships that "a ruler should act as a ruler and a servant should behave as a servant." Unlike the first example, this way of thinking is a clear impediment to the modernization of Confucianism.

However, the thought of Mencius and Xunzi also contains elements that are irreconcilable. Therefore, it is necessary to do a profit-loss analysis for both schools of thought. Otherwise, they will repel and reject one another.

As far as I can see, there are two main patterns for analysis. The first affirms one party while disavowing the other, such as affirming Mencius' idea that "the people are more important than the ruler" and disavowing Xunzi's support of autocracy. The second decides that neither position should be maintained. One obvious case of this is where Mencius says "human nature is good" and Xunzi says "human nature is evil." This kind of nature versus nurture debate is quite outdated, as the existence of something called "human nature" can be neither proven nor disproven. I am personally in more agreement with Wang Fuzhi's 王夫之 [1619-1692] view on human nature: "the disposition of one's heart is something that endlessly changes through daily experience and

52 He Yan 何晏, annot., and Xing Bing 邢旵, collat., "Lunyu zhushu 論語注疏 [Annotations on the Analects]," in Shisanjing zhushu 十三經注疏 [Notes and Commentaries on the Thirteen Classics], ed. Ruan Yuan 阮元 (Beijing: Zhonghua shuju, 1980), 2463. Zhao Qi 趙岐, annot., and Sun Shi 孫顛, collat., "Mengzi zhushu 孟子注疏 [Annotations on the Mencius]," in Shisanjing zhushu, 2755.

54 See Wang Xianqian 王先謙, Xunzi ji jie 荀子集解 [Collection and Explication of Xunzi's Works], in Xinbian zhuzi jicheng 新編諸子集成 [The New Version of Collected Interpretations of Zhuzi] (Beijing: Zhonghua shuju, 1988), 442. 
development." ${ }^{55}$ Thus, human nature is not unchanging but grows and develops within the context of life.

3.2 .2

Profit-Loss Analysis of the Thought of Mencius and Xunzi Based on the Historical-Period Context

The historical context is a dimension of utmost importance when it comes to a profit-loss analysis of Mencius and Xunzi's respective schools of thought. This is because the value systems that inform the very idea of "profit" and "loss" reflect the values of human civilization and society at any given time. Otherwise, they just devolve into fundamentalism.

Loss: We must abandon the aspects of the thought of Mencius and Xunzi that are not modern. Many elements of their teachings were relevant to their time but of no use in the present, which operates on the basis of a vastly different set of civilizational values. A few critical examples of the kinds of elements that must be abandoned are those that are incompatible with modern ideas of freedom, equality, justice, democracy, and law.

Profit: We would benefit from innovatively building on the ideas of Mencius and Xunzi. When considering the needs of modern society and life, many of Mencius and Xunzi's ideas are far from complete and in need of development and supplementation. In doing so, it is especially important to avoid regressive tendencies in academia that oppose civilizational progress.

Apart from these two points, there is also the question of incorporating Chinese and Western perspectives. Here, it is worth considering the words of Zhang Taiyan:

Nowadays, if you want to be Xunzi's discipline, you can find all the Western discourses here. Please study accordingly. If you want to be Mencius' disciple, you must study works on rituals and music going back beyond the three periods of antiquity. After the works of the seventy-two disciples of Confucius, you must then master the scholarly works of the Han and Tang dynasties as well as the fruits of 240 years of diligent study by scholars in the Qing to the present. ${ }^{56}$

Zhang's casual characterization of Xunzi as a Western scholar and Mencius as traditional is arguable. However, the juxtaposition of "integrating Mencius and Xunzi" with "integrating China and the West" is a maneuver worth affirming.

55 Wang Fuzhi 王夫之, Chuan shan quanshu 船山全書 [Complete Works of Wang Fuzhi] (Changsha: Yuelu shushe, 1996), 2.30o.

$56 \quad$ Zhang Taiyan, Zhang Taiyan quanji, 3.7. 
I would like to add that the issue is not actually one of China versus the West, but classical versus modern or premodern versus modern. As I have pointed out many times elsewhere, we must resist the academic tendency to bury questions of historical change in discussions regarding the difference between China and the West. This is effectively a disavowal of modern civilization.

I conclude by way of summary. The thought of Mencius and Xunzi has many inherent complexities and contradictions, as they have been revised, reconstituted, and reused alongside shifts in lifestyles and social structures; their respective influence also waxed and waned accordingly. Xunzi's teachings flourished during China's transition from monarchical feudalism to imperial autocracy, an indication that they have Legalist elements. The rulers of the imperial period "solely venerated Confucian learning," so the suspiciously Legalist teachings of Xunzi went into decline while the orthodox Confucian teachings of Mencius were on the rise. At the same time, Xunzi's thought continued to play an important, perhaps even fundamental, role in hidden ways. This is what came to be known as the political path of being "openly Confucian, covertly Legalist," practiced by autocratic rulers. As Chinese society began to modernize, Xunzi's teachings enjoyed a revival, revealing strains that were compatible with modern Enlightenment ideas. However, this revival of Xunzi's thought occurred along with a revival of Confucianism, so it did not result in a subsequent decline in Mencius' influence. This raises the need to rethink the two schools of thought in an integrated way. To accomplish this, we must take a page from modern value systems and consider existing distinctions between Mencius' and Xunzi's thinking using analyses of associated "profit and loss."

\section{Translated by Casey Lee}

\section{Works Cited}

Ban Gu 班固. Han shu 漢書 [History of the Former Han Dynasty]. Beijing: Zhonghua shuju, 1962.

Chang Daqun 常大群. “Xunzi yu Zhongguo junzhu zhuanzhi zhengti 荀子與中國君主 專制政體 [Xunzi and Chinese Autocratic Governance].” Zaozhuang shizhuan xuebao 霖莊師專學報, no. 1 (1992): 88-92.

Fang Erjia 方爾加. “Xunzi: Kong Meng Rujia de qiangu zuiren 荀子: 孔孟儒家的千古 罪人 [Xunzi: Eternal Sinner of Orthodox Confucianism].” Guan zixuekan 管子學刊, no. 4 (1994): 20-24.

Fang Erjia 方爾加. Xunzi xin lun 荀子新論 [New Discussions on Xunzi]. Beijing: Zhongguo heping chubanshe, 1993 . 
Feng Youlan 馮友蘭. “Zhongguo zhexue yichan di jicheng wenti 中國哲學遺產底繼承 問題 [The Problem of Inheriting of China's Philosophical Heritage]." Guangming ribao 光明日報, January 8, 1957 .

Feng Youlan 馮友蘭. “Zai lun Zhongguo zhexue yichan di jicheng wenti 再論中國哲 學遺產底繼承問題 [Revisiting the Problem of Inheriting China's Philosophical Heritage]." Zhexue yanjiu 哲學研究, no. 5 (1957): 73-81.

Goldin, Paul, ed. Dao Companion to the Philosophy of Han Fei. Dordrecht: Springer, 2013.

Guo Yi 郭沂. "Shou zhi yi Xun, jiu zhi yi Meng: xiandaihua beijing xia de Rujia chongjian 受之以荷, 糾之以孟: 現代化背景下的儒家重建 [Received According to Xunzi, Rectified According to Mencius: Rebuilding Confucianism in the Context of Modernization]." Wen shi zhe 文史哲, no. 2 (2020): 103-8.

$\mathrm{Han} \mathrm{Yu}$ 韓愈. Han Changli wenji jiaozhu 韓昌黎文集校注 [Annotated Collected Works for Han Changli], annotated by Ma Qichang 馬其昶. Shanghai: Shanghai guji chubanshe, 1987 .

$\mathrm{Hu}$ Shi 胡適. Hu Shi yigao ji micang shuxin 胡適遺稿及秘藏書信 [Unpublished Manuscripts and Private Letters of Hu Shi]. Hefei: Huangshan shushe, 1994.

Huang Yushun 黃玉順. “Lun 'chong xie ruxue shi' yu 'ruxue xiandaihua banben' wenti 論“重寫儒學史”與“儒學現代化版本”問題 [On the Problem of ‘Rewriting the History of Confucianism' and 'the Modernized Version of Confucianism']." Xiandai zhexue 現代哲學, no. 3 (2015): 97-103.

Huang Yushun. "Dalu xin rujia zhengzhi zhexue de xianzhuang yu qianjing 大陸新儒家 政治哲學的現狀與前景 [The Current State and Future Prospects of New Confucian Politics on the Mainland]." Hengshui xueyuan xuebao 衡水學院學報, no. 2 (2017): 69-71.

Huang Yushun. “Kongzi zenyang jiegou daode: Rujia daode zhexue gangyao 孔子怎樣 解構道德: 儒家道德哲學綱要 [How Confucius Structures Ethics: An Outline of the Confucian Philosophy of Ethics].” Xue shujie 學術界, no. 11 (2015): 104-15.

Huang Yushun. "Lun ruxue de xiandai xing 論儒學的現代性 [On the Modernity of Confucianism]." Shehui kexue yanjiu 社會科學研究, no. 6 (2016): 125-35.

Huang Yushun. “Rujia ziyou zhuyi dui 'xin ru jiao' de piping 儒家自由主義對 ‘新儒教’ 的批評 [Confucian Liberalist Critique of 'New Confucian Teachings'].” Dongyue lun cong 東茯論叢, no. 6 (2017): 39-44.

Huang Yushun. “Ruxue dangdai fuxing de sixiang shiyu wenti 儒學當代復興的思想視 域問題 [On the Problem of Ideological Scope and Perspective Regarding the Revival of Confucianism Today]." Zhouyiyanjiu 周易研究, no. 1 (2008): 104-115.

Huang Yushun. "Ruxue de xianzhuang, jiaoxun yu jingyan: zhengzhi zhexue cengmian de guancha yu sikao 儒學的現狀, 教訓與經驗: 政治哲學層面的觀察與思考 [The Current Situation, Lessons, and Experiences of Confucian Studies: Observations and Considerations of Political and Philosophical Aspects]." In Shenghuo ruxue yu xiandaixing wenti 生活儒學與現代性問題 [Living Confucianism and the Problem 
of Modernity], edited by Huang Yushun 黃玉順, 251-56. Chengdu: Sichuan renmin chubanshe, 2019.

Huang Yushun. "Ruxue zhi dangqian taishi yu weilai zhuwang 儒學之當前態勢與未 來矚望 [The Current State and Future Hopes of Confucian Studies].” Kongzi yanjiu 孔子研究, no. 4 (2018): 17-21.

Huang Yushun. Zhexue duanxiang: “Shenghuo ruxue” xinzha 哲學斷想: “生活儒學” 信答 [Fragmented Thoughts on Philosophy: Letters on Living Confucianism]. Chengdu: Sichuan renmin chubanshe, 2019.

Huang Yushun. Zhongguo zhengyi lun de chongjian: Rujia zhidu lunlixue de dangdai chanshi 中國正義論的重建: 儒家制度倫理學的當代闡釋 [Rebuilding a Chinese Theory of Justice: Contemporary Interpretations of Confucian Systems of Human Ethics]. Hefei: Anhui renmin chubanshe, 2013.

Huang Yushun. Zhongguo zhengyi lun de xingcheng: Zhou Kong Meng Xun de zhidu lunli xue chuantong 中國正義論的形成: 周孔孟荀的制度倫理學傳統 [The Making of China's Theory of Justice: The Tradition of Confucian Ethics in Zhou, Confucius, Mencius, and Xunzi]. Shanghai: Dongfang chubanshe, 2015.

Huo Shengyu 霍生玉. "Han Yu zhushi guo Xunzi ma? Tangdai Yang Liang Xunzi zhu zhong 'Han shilang' kao 韓愈注釋過《荷子》嗎一唐代揚倞《荷子注》中 ‘韓侍 郎' 考 [Did Han Yu Ever Annotate the Xunzi? A Study of 'Deputy Minister Han' in the Annotated Xunzi of Tang Dynasty Figure Yang Liang]." Guji yanjiu 古籍研究, no. 2 (2013): 20-25.

Li Zehou 李澤厚. “Lun lixue buzhu 倫理學補注 [Additional Annotations to Discussions of Neo-Confucianism].” Tansuo yu zhengming 探索與爭鳴, no. 9 (2016):4-13.

Li Zehou 李澤厚. “Ju Meng qi, xing Xun xue: wei ‘lun lixue gang yao’ yibian 舉孟旗, 行荷學: 為《倫理學綱要》一讋 [Raising Mencius's Banner, Practicing Xunzi's Teachings: An Argument for Lun lixue gangyao].” Tansuo yu zhengming 探索與爭鳴, no. 4 (2017): 57-62.

Liang Qichao 梁啟超, ed. Yin bing shi he ji 飲冰室合集 [Collected Works from the Ice-Drinking Room]. Beijing: Zhonghua shuju, 1989.

Liang Qichao 梁啟超. Xian Qin zhengzhi sixiang shi 先秦政治思想史 [An Intellectual History of the Early Qin]. Tianjin: Tianjin guji chubanshe, 2003.

Liang Tao 梁濤. “Chaoyue zun Meng yi Xun, huigui tongzun Meng-Xun 超越尊孟 抑荷, 回歸同尊孟 [Transcending 'Venerate Mencius, Suppress Xunzi': Returning to Venerating both Masters].” Wen shi zhe 文史哲, no. 2 (2020): 113-18.

Liang Tao 梁濤. “Kong Meng zhijian 孔孟之間 [Between Confucius and Mencius]." Zhonghua dushubao 中華讀書報, October 25, 2017.

Liang Yusheng 梁玉繩. Shiji zhiyi 史記志疑 [Inconsistencies in the Records of the Grand Historian]. Beijing: Zhonghua shuju, 1981.

Liu Junwen 劉俊文, ed. Riben xuezhe yanjiu Zhongguo shi lunzhu xuanyi 日本學者研 究中國史論著選譯 [Select Translations of Chinese Historical Research by Japanese Scholars]. Beijing: Zhonghua shuju, 1992. 
Liu Yuedi 劉悅笛. “Meng Xun 'tian, xing, qing, xin' tonghe lun: cong 'xintong qingxing' xinshijiao jiantiao Xun Meng 孟荀‘天, 性, 情, 心’ 統合論: 從‘心統情性’新視角兼祧 荀孟 [A Theory of Incorporating Mencius's and Xunzi's 'Heaven, Nature, Emotions, Mind': Inheriting Both Mencius and Xunzi from the New Perspective of 'Unifying Nature and Emotions via the Mind']." Wen shi zhe 文史哲, no. 2 (2020):109-12.

Luo Guanzhong 羅貫中. Sanguo yanyi 三國演義 [Romance of the Three Kingdoms]. Beijing: Renmin wenxue chubanshe, 1973.

Mou Zongsan 牟宗三. Xintiyu xingti 心體與性體 [Substance of the Mind and of Nature]. Changchun: Jilin chuban jituan youxian gongsi, 2013.

Naitō Torajirō 内藤湖南. “Gaikatsu teki Tōsō jidai kan 概括的唐宋時代観 [A General Perspective on the Period from the Tang to Song Dynasties].” Rekishi to chiri 歴史と 地理 9, no. 5 (1910): 1-12.

Qian $\mathrm{Mu}$ 錢穆. Zhongguo jin sanbainian xueshushi 中國近三百年學術史 [A History of Chinese Scholarship in the Past Three Hundred Years]. Shijiazhuang: Hebei jiaoyu chubanshe, 1999.

Ruan Yi 阮逸, annot. “Zhongshuo 中說 [Discourses on the Mean].” In Sibu congkan chubian 四部叢刊初編 [First Series of the Four Branches of Literature Collection].

Ruan Yuan 阮元, ed. Shisanjing zhushu十三經注疏 [Notes and Commentaries on the Thirteen Classics]. Beijing: Zhonghua shuju, 1980.

Sa Mengwu 薩孟武. Zhongguo zhengzhi sixiang shi 中國政治思想史 [History of Chinese Political Thought]. Beijing: Dongfang chubanshe, 2008.

Sima Qian 司馬遷. Shiji 史記 [Records of the Grand Historian]. Beijing: Zhonghua shuju, 1959 .

Sun Dakun 孫大坤. “Wan Qing yujing zhong de Xunxue jieshi 晚清語境中的荀學解 釋 [Explaining Xunzi in the Context of the Late Qing]." In Jingdian yu Jieshi 經典與 解釋 [Classics and Explications], edited by Lou Lin 娄林, 49.211-32. Beijing: Huaxia chubanshe, 2018.

Tan Sitong 譚嗣同. Ren xue 仁學 [Study on Benevolence]. Beijing: Huaxia chubanshe, 2002.

Tan Sitong 譚嗣同. Tan Sitong quanji 譚嗣同全集 [The Complete Works of Tan Sitong], edited by Cai Shangsi 蔡尚思 and Fang Xing 方行. Beijing: Zhonghua shuju, 1981.

Wang Fuzhi 王夫之. Chuan shan quanshu 船山全書 [Complete Works of Wang Fuzhi]. Changsha: Yuelu shushe, 1996.

Wang Ling 王玲. “Xian Qin Rujia de ‘jun chen zhi fen’ tan ze先秦儒家的“君臣之分”探 賾 [Investigation into the Pre-Qin Confucian Idea of 'Division between Lord and Servant']." Hebei shifan daxue xuebao 河北師範大學學報, no. 2 (2012): 30-36.

Wang Xianqian 王先謙. “Xunzi ji jie 荀子集解 [Collection and Explication of Xunzi's Works].” In Xinbian zhuzi jicheng 新編諸子集成 [The New Version of Collected Interpretations of Zhuzi]. Beijing: Zhonghua shuju, 1988.

Wang Zhong 汪中. Shuxue jiaojian 述學校箋 [A Collation and Commentary on the Shuxue]. Beijing: Zhonghua shuju, 2014. 
Xu Fuguan 徐複觀. Liang Han sixiang shi 兩漢思想史 [Intellectual History of the Two Han Dynasties]. Shanghai: Huadong shifan daxue chubanshe, 2001.

Xu Pingzhang 徐平章. Xunzi yu liang Han Ruxue 荀子與兩漢儒學 [Xunzi and Confucianism of the Two Han Dynasties]. Taibei: Wenjin chubanshe, 1988.

Zhang Taiyan 章太炎. Zhang Taiyan quanji 章太炎全集 [The Complete Works of Zhang Taiyan]. Shanghai: Shanghai renmin chubanshe, 1985.

Zhao Fasheng 趙法生. “Xunzi de zhengzhi sheji yu xuepai guishu 荀子的政治設計與 學派歸屬 [Xunzi's Political Designation and the School of Thought to Which He Belongs]." Zhexue yanjiu 哲學研究, no. 5 (2016): 68-77.

Zhou Yutong 周予同. Zhou Yutong jingxue shi lunzhu xuanji 周予同經學史論著 選集 [Collection of Select Works by Zhou Yutong on the History of Classical Studies]. Shanghai: Shanghai renmin chubanshe, 1996.

Zhu Weizheng 朱維錚. "Shenzhou changye shui zhi jiu: xi Xia Zengyou yu Song Shu de tongxin 神州長夜誰之处一析夏曾佑與宋恕的通信 [Whose Error during a Long Night in Shenzhou: Analyzing the Correspondence between Xia Zengyou and Song Shu]." In Yindiao weiding de chuantong 音調未定的傳統 [Collected Works of Zhu Weizheng], edited by Zhu Weizheng 朱維錚, 146-57. Hangzhou: Zhejiang daxue chubanshe, 2011. 